\title{
1. Introduction: a dissenter's view of the development of growth theory and the importance of demand-led growth
}

\section{Mark Setterfield}

Growth theory has enjoyed a somewhat chequered history in the development of economic thought, despite having been a defining feature of economic analysis during the century that followed the publication of Smith's Wealth of Nations. The works of Ricardo, Malthus, Mill and Marx - and even, as Nicholas Kaldor often pointed out, the early chapters of the Wealth of Nations itself - all attached central importance to issues of accumulation and growth. But in the wake of the late nineteenth-century marginalist revolution, with its emphasis on exchange, resource allocation and price determination, growth became a topic of secondary importance. The work of Harrod and Keynes in the 1930s revitalized interest in growth, and this interest remained central to the development of both neoclassical and Keynesian economic theory throughout the 1950s and 1960s. But growth theory is commonly believed to have lost its momentum once again thereafter. Indeed, it is now commonplace to refer to there recently having been a revival in growth theory, marked by the contributions of Romer (1986) and Lucas (1988) and the subsequent development, during the 1990s, of neoclassical endogenous growth (NEG) theory.

The alleged hiatus in growth theory during the 1970s and 1980s is, however, more apparent than real. The popularity of this idea is more representative of the overwhelming attention that has been paid to supply-side analyses of macroeconomic processes since the beginning of the classical counter-revolution, than of any genuine suspension of the development of growth theory after the late 1960s. In fact, the 1970s and 1980s witnessed some key contributions to the theory of demand-led growth - contributions on which many of the chapters in this volume seek to build. For example, Cornwall (1972) identified the reconciliation of the growth of demand with that of supply as one of the central issues in growth theory. In so doing, he rejected the neoclassical claim that demand adjusts passively to accommodate supply - so that the study of the supply side and the growth of potential output 
is all that is essential to growth theorists - in favour of a vision based on the Keynesian principle of effective demand. ${ }^{1}$ For Cornwall, a central organizing principle of growth theory is 'Say's law in reverse', according to which the expansion of supply (and hence potential output) responds to the expansion of demand (and hence actual output). A central question then becomes the elasticity of this supply response with respect to the expansion of demand, upon the answer to which turns the prospects for stable growth without either everexpanding excess capacity or excess demand. ${ }^{2}$

Meanwhile, Kaldor's (1970, 1972, 1981, 1985) championing of the Veblen-Myrdal notion of cumulative causation as the basis for a non-equilibrium growth theory resulted in his developing a theory of demand-determined growth in which the rate of growth of exports is the proximate determinant of income growth. The subsequent development of Kaldor's thinking (see, for example, Dixon and Thirlwall, 1975) inspired balance-of-payments-constraint growth (BPCG) theory (Thirlwall, 1979) from which Thirlwall's law - an empirically robust association between income growth, the income elasticity of demand for imports and the rate of growth of exports - emerges. ${ }^{3}$

The relationship between distribution and growth - central to the Kaleckiinspired Cambridge growth theory associated with, for example, Robinson (1956) - became an important constituent of the neo-Kaleckian growth models first developed during the 1970s and 1980s (see, for example, Harris, 1974, Asimakopulous, 1975, Rowthorn, 1982 and the various other contributions surveyed in Chapter 8). At the core of this literature is the question as to whether a redistribution of income away from wages and towards profits is capable of boosting growth, given the negative impact of a rising profit share of income on consumption spending, coupled with its positive impact on investment expenditures. Neo-Kaleckian models have explored the conditions necessary for growth to be either wage-led or profit-led, extending this analysis to incorporate open economy effects on growth, and to link growth dynamics with those of conflict-based inflation. ${ }^{4}$

During the 1970s and 1980s, demand-led growth theorists also developed a concern with the importance of the composition rather than simply the amount of demand as an influence on growth. Cornwall (1977) described growth as a process of movement through a commodity hierarchy, in which demand for the outputs of various sectors of the economy - agriculture, manufacturing and services - is characterized by a series of Engel curves which together form a 'hierarchy of commodities'. 5 The resulting transformation of the composition or structure of demand in the course of growth is shown to impact the rate of growth itself. The emergence of Transformational Growth theory (see, for example, Nell, 1992) helped to consolidate and extend these insights into the links between growth and structural change. Part of the purpose of Transformational Growth theory has been to provide a thorough 
account of the growth and development of demand itself in the course of capitalist history, from the earliest beginnings of the factory system through to the emergence of mass markets and the development of the modern state. ${ }^{6}$

It is thus possible to write a history of contemporary growth theory in which the 1970s and 1980s appear as part of a more-or-less continuous development of ideas first introduced in the 1930s by Harrod and Keynes. As intimated earlier, however, this is not how most contemporary histories of growth theory are, in fact, written. Moreover, having been overlooked in accounts of the recent development of growth theory, it is not surprising to find that contributions to demand-led growth theory have also been neglected in the period since the emergence of NEG theory. This is because NEG theory, like its neoclassical forebear the Solow model (Solow, 1956), provides a relentlessly supply-oriented account of the growth process, in which demand adjusts passively to accommodate the expansion of potential output. The most important difference between NEG theory and the Solow model is that, in the former, the marginal productivities of accumulable factors of production (such as physical capital, human capital, and new 'know-how' or technology) are bounded from below above zero. In other words, continual accumulation of these factors does not exhaust their contribution to production at the margin, so that it is possible to sustain growth through a steady process of accumulation. This is impossible in the Solow model, in which the marginal productivity of capital eventually diminishes to zero. This, in turn, rules out the possibility of sustaining growth through the continual accumulation of capital, something that is codified in one of the most famous results of the model, which suggests that changes in the propensity to save (and hence to accumulate, since saving is identical to investment in Solow) cannot affect the longrun growth rate. In NEG theory, however, anything that affects the savings rate will affect the long-run rate of growth, given the conventional neoclassical hypothesis that saving causes investment.

The essential difference between these first and second generation neoclassical growth theories, then, is the assumptions that they make about the technical properties of (accumulable) inputs into the production process. They are essentially similar, however, in their technocratic treatment of production, which pays no heed to Marx's argument that social as well as technical relations of production should always be at the forefront of any analysis of the conditions of supply. And more importantly for the purposes of this volume, the Solow model and NEG theories are similar in their treatment of growth as an essentially supply-side process. Since savings creates investment, effective demand failures are impossible, and autonomous changes in aggregate demand can only impact the utilization of resources in the short run as long as expectational errors or nominal rigidities - both of which are held to be transitory phenomena - interrupt the otherwise neutral (in terms of their impact on 
real variables) adjustment of prices. Meanwhile, the supply-determined potential output path of the economy - towards which the actual output path of the economy is attracted in the long run - is conventionally assumed to be independent of variations in demand and the transitory differences between actual and potential output to which these give rise. Demand is thus denied even an indirect influence on growth. ${ }^{7}$

The chapters in this volume rest on challenges to both of these propositions - that demand has only a transitory impact on the utilization of resources, and that the development of these resources (and hence of potential output) over time is independent of demand. In the first place, the role of demand in influencing the utilization of productive resources is understood to be chronic: there is no supply-determined equilibrium acting as a centre of gravity towards which the level of economic activity is inevitably and inexorably drawn. Instead, at any point in time, the utilization of existing productive resources is fundamentally demand-determined. What this, in turn, implies is that the actual output path of the economy, which describes its growth trajectory, is demand-determined. In other words, the sequence of short-run outcomes associated with the demand-determined utilization of productive resources traces out the economy's long-run growth trajectory, in a manner that is relatively autonomous of the conditions of supply defining the potential output path of the economy, which does not act as a strong attractor as in neoclassical growth theory. ${ }^{8}$ This draws attention to an important methodological feature of demand-led growth theory, according to which the long run is understood to be an ongoing process (the result of which is the historical sequence of shortrun outcomes alluded to above) rather than a predefined position towards which the economy inevitably 'tends'. This conception of the long run as a process is discussed further in Chapter 12, the focus of which is the principle of the traverse. However, it is equally obvious in the numerous chapters that make explicit use of equilibrium as an organizing concept in their discussions of long-run growth, and which either implicitly or explicitly acknowledge that what they are describing are positions of conditional or provisional equilibrium. ${ }^{9}$ These are positions that do not possess the mechanical stability properties of conventional equilibria, and/or which may not be indefinitely reproduced over time as 'states of rest', even if the economy is able to 'get into' such a position initially (Setterfield, 1997a; Chick and Caserta, 1997).

Second, the very development of productive resources over time is influenced by demand. Supply conditions do not define the potential output path of the economy independently of the demand-determined actual output path. For example, the availability of labour is influenced by the realized level of economic activity, which can impact labour force participation rates, patterns of migration and the sectoral structure of employment (Cornwall, 1977). Capital accumulation is similarly influenced by realized output and hence 
demand, via accelerator effects. ${ }^{10}$ And finally, technological change is demand-determined (and hence endogenous to the growth process), as was first recognized by Kaldor in his development of the technological progress function (Kaldor, 1957) and subsequent championing of the Verdoorn law. ${ }^{11}$ Technical progress is induced by demand-led growth in part because of the fact that different vintages of capital embody different states of technology. Hence investment always contributes to aggregate demand, the available stock of capital and average productivity. Moreover, expansions of demand, by stimulating the amount of economic activity, can stimulate the amount of learning-by-doing in an economy, while the process of innovation is also influenced by demand (Schmookler, 1966; Brouwer and Kleinknecht, 1999). ${ }^{12}$

In sum, the natural rate of growth is ultimately endogenous to the demanddetermined actual rate of growth. As discussed earlier, the natural rate is not an attractor in demand-led growth models - it does not constitute a centre of gravity towards which the economy automatically tends. Instead, by determining the potential output of the economy, the natural rate defines a ceiling to the level of economic activity at any given point in time. What we are now saying, however, is that this ceiling is not exogenously determined by supplyside forces. Rather, it is sensitive to the demand-determined actual rate of growth. The potential output path of the economy, which defines the maximum level of activity achievable at any point in time, cannot be exceeded by the actual output path. But the potential output path is elastic with respect to the actual output path, so that it is ultimately possible to speak of the former as well as the latter as being demand-led.

Note that this interaction between the actual and potential rates of growth also draws explicit attention to a second methodological feature of demand-led growth analysis, which is closely related to the first - the importance attached to the principle of path dependence. Just as any of the conditional or provisional growth equilibria described earlier may be influenced by the rate of growth actually achieved by the economy (see Chapter 12), so, too, may the potential rate of growth be influenced in the same way. From this point of view, the essence of macrodynamic analysis is to begin with the short run, and to understand the long run as a historical (path-dependent) sequence of these short-run outcomes. Whether viewed in terms of the actual rate of growth achieved or the maximum rate of growth achievable, the point is that the long-run trend is . . a a slowly changing component of a chain of short-period situations' (Kalecki, 1971, p. 165) rather than a preordained trajectory.

The remainder of this volume is organized into five sections. The resulting division of chapters is somewhat false, not least because the issues that are confronted in each section - such as the impact of distribution on growth, the reconciliation of the growth of demand and supply in the long run, the importance of international factors and so on - frequently overlap. Nevertheless, the 
division is retained because it does serve a useful organizational purpose, by grouping together chapters that are concerned with a particular facet of or approach to analysing demand-led growth.

The first section addresses Fundamental Issues in the Theory of Demandled Growth and, in particular, the contrast between demand- and supply-led visions of the growth process, the importance of the separation of investment and saving and the empirical significance of demand-led growth. Thomas Palley examines the compatibility of short-period Keynesian analysis with long-run growth theory, arguing that central to this compatibility is the idea of an endogenous natural rate of growth that is sensitive to the evolution of aggregate demand. Palley begins by describing the Solow model, which he takes to be paradigmatic of 'old' growth theory. It is shown that this model is consistent with both new classical macroeconomics and neoclassical-synthesis Keynesianism. Each of these theories postulates that the economy progresses along a supply-determined, full employment, steady-state growth path in the absence of shocks, the occurrence of which causes transitory departures from (but has no effect on the intrinsic nature of) the trend rate of advance. However, the Solow model is not compatible with 'fundamentalist' Keynesianism, according to which the economy advances along a realized output path characterized by a sequence of demand-constrained equilibria, displaying no automatic tendency to gravitate towards a supply-determined, steady-state growth trajectory consistent with full employment.

Palley then introduces the notion of endogenous growth, according to which the long-run rate of growth is influenced by the process of accumulation. It is shown that both new classical macroeconomics and neoclassicalsynthesis Keynesianism can be reconciled with endogenous growth theory. More importantly for Palley, so, too, can fundamentalist Keynesianism. This is perhaps not surprising, as Kaldor's (1957) technical progress function is identified as the progenitor of endogenous growth theory, and Kaldor's cumulative causation models (based on the recursive and self-reinforcing interaction of demand and productivity growth) anticipate NEG theory by two decades. To demonstrate his point, Palley develops a model of endogenous growth in which both the level and the rate of growth of demand enter into the determination of the long-run equilibrium growth rate. The chapter ends with a critical examination of two other models that seek to integrate demand into the analysis of long-run growth - the model of unbalanced growth developed by Cornwall and Cornwall (1994) and the BPCG model due originally to Thirwall (1979).

Joseph Halevi and Réduane Taouil identify the principle of effective demand as developed by Keynes and Kalecki as the major conceptual distinction between Keynesian economics on one hand, and both neoclassical and classical economics on the other. Both Keynes and Kalecki conceive capitalism as an 
open system, in which the level of economic activity - and its growth and fluctuations over time - are essentially indeterminate. The leading element in the analyses of both Keynes and Kalecki is investment spending, the relative autonomy of which is the proximate source of openness in their models of economic activity.

Halevi and Taouil first describe a Marxian model of accumulation, demonstrating how its results are radically altered by the introduction of effective demand considerations. The latter arise from the separation of investment and savings decisions, and the inability of increases in saving to automatically generate more investment spending. In other words, investment spending is established as an independent variable, rather than a dependent variable (dependent, specifically, upon savings) as in the Marxian model. They then discuss the treatment of investment as the determinant of the level and distribution of income in Kalecki, and as the determinant of the level of income in Keynes. In both cases, it is shown that the level of investment spending is essentially indeterminate - so that while it can be stated that there exists a causal relationship between changes in investment and changes in income, this causal relationship is not reducible to a mechanical 'law of motion' from which the evolution of income can be deduced and predicted. More specifically, fluctuations in investment cannot be reduced to foreclosed explanation in terms of supply-side variables, which would permit deterministic explanation of variations in demand and total income in terms of changes emanating from the supply side. Instead, the long run is conceived as an inter-temporal sequence of short runs, in each of which autonomous, demand-side forces are the essential determinants of the level of economic activity. Capitalism as viewed through the lens of the principle of effective demand is, therefore, an open system, in which fluctuations in and the growth of output over time are indeterminate, historical processes.

Motivated by neoclassical claims that the long-run growth of output is driven by real factors on the supply side of the economy, Sonmez Atesoglu investigates the roles of money and autonomous expenditures (including investment, government spending and exports) in determining the path of real output. Using quarterly data for the US economy from 1960-97, he first establishes that real gross domestic product (GDP), investment, government spending, exports and the M2 money supply are all integrated of order one. Atesoglu then shows that real output is cointegrated with investment, government spending, exports and the money supply, that there is bidirectional causality among real output, investment and the money supply and that there is unidirectional causality from government spending and exports to real output. In other words, there exist long-run relationships between real output and precisely the monetary and demand-side variables that are routinely overlooked in neoclassical growth theory. Moreover, there are feedback effects 
from real output to both investment and the money supply. These are precisely the relationships that post-Keynesian macroeconomic analysis, with its emphasis on the non-neutrality of money and the importance of aggregate demand (even in the long run), would predict. Atesoglu concludes by remarking upon the policy implication of his results, which is that demand-management can have potent effects on real output in both the short and long run.

The second section contains chapters on various Kaldorian Models of Demand-led Growth. Kaldor's development of the Veblen-Myrdal concept of cumulative causation has inspired a subsequent generation of growth theorists to consider the two-way or joint interaction between the growth of demand and supply, while his focus within the same analysis on the importance of interregional trade ultimately gave rise to contemporary BPCG theory. The chapters in this second section reflect these different facets of contemporary Kaldorian growth analysis. Mark Setterfield and John Cornwall develop a neoKaldorian model of growth, which is used to explain changes in the rates of growth of output and productivity in the advanced capitalist economies since the Second World War. The basic theoretical insight is that the parameters of a standard Kaldorian model of cumulative causation can be treated as being institutionally determined. Different parameter values, corresponding to different, relatively enduring 'institutional regimes' in capitalist history, can then be used to characterize different episodes of capitalist growth performance. Three such episodes are identified: the Golden Age (1945-73), the Age of Decline (1973-89) and a new growth episode in the USA during the 1990s. In each case, historically specific institutions are shown to give rise to different demand and productivity regimes, whose cumulative interaction explains differences in the growth performance of capitalist economies between different growth episodes.

The focus of the chapter by John McCombie and Mark Roberts is the importance that attaches to the growth of exports in the determination of economic growth, not just because of the direct contribution of increasing export demand to demand-led growth, but because export growth provides a basis for faster expansion of domestic demand (and hence more 'homespun' growth) without the latter resulting in balance-of-payments difficulties. ${ }^{13}$ This result is, of course, encapsulated in Thirlwall's law, which equates the longrun rate of growth with the product of export growth and a dynamical version of the foreign trade multiplier.

McCombie and Roberts demonstrate that financial flows - which have become an increasingly significant feature of the international environment in recent decades - cannot significantly relax the BPCG rate. The claim that BPCG theory is flawed owing to a fallacy of composition is rebutted, and the criticism that Thirlwall's law is a traditional equilibrium theory of growth that does not accord with Kaldor's vision of growth as a historical process is 
addressed. As regards the latter, it is shown that by endogenizing the income elasticities of demand for exports and imports, the dynamics of the BPCG model can be made chaotic. This renders its growth outcomes path dependent in the sense of being highly sensitive to initial conditions. Finally, McCombie and Roberts survey recent empirical investigations of Thirlwall's law, with a particular emphasis on the ability of this law to explain the rapid rates of growth experienced in East Asia since the mid-1960s.

In a chapter that picks up from the contributions of Cornwall (1972) discussed earlier, Thomas Palley argues that an important agenda for demandled growth theory is to model not just the rate of growth of demand, but also the rate of growth of supply and (crucially) the interaction between the two. ${ }^{14}$ This helps render explicit the 'Say's law in reverse' property of demand-led growth models, and also draws attention to the need for the rates of growth of supply and demand to be reconciled if a growth path is to be sustainable in the long run. Palley demonstrates the importance of this latter point in the context of a BPCG model. This model is shown to be overdetermined, giving rise to two rates of growth (a rate of growth of demand and a rate of growth of supply) whose equivalence is a special case. Palley then proposes various resolutions to this problem, based on demand- or supply-side adjustments to changes in the rate of capacity utilization. For example, it is postulated that the income elasticity of demand for imports may be a negative function of excess capacity. This is because as excess capacity falls, bottlenecks in domestic industry become more prevalent, and these supply constraints increase the proportion of incremental income that is spent on imports. As a result, the rate of growth of demand that is consistent with a given rate of growth of world income (as determined by Thirlwall's law) adjusts towards the rate of growth of demand consistent with supply growth (as determined by the rate of growth of the labour force and Verdoorn's law).

The third section of the book, entitled Kaleckian Models of Demand-led Growth, builds on the Kalecki-Robinson tradition in Cambridge growth theory, according to which the rates of accumulation and profit are determined by a two-sided relationship between investment and profits. On one hand, investment determines profits through a Keynesian income-generating mechanism. On the other, profits determine investment, both by fuelling expectations of the future profitability of investment, and by influencing firms' access to finance. An important theme in this literature is the impact of changes in the distribution of income on the rates of capacity utilization and growth, a comprehensive account of which is found in the chapter by Robert Blecker. Blecker begins by developing a traditional Kaleckian growth model, which is stagnationist and exhibits wage-led growth. In other words, an increase in the profit share of income reduces capacity utilization and the rate of growth. The remainder of the chapter then shows how various extensions to and modifications of this 
basic model can render other results more likely. For example, Blecker shows that the possibilities of exhilarationism (an increase in the profit share raises the rate of capacity utilization) and profit-led growth (an increase in the profit share raises the rate of growth) are enhanced by modifications to the investment function which place greater emphasis on the importance of the profit share in the determination of investment plans; allowance for savings out of wages and the effects of taxation (both of which reduce the "consumption dividend' associated with a rise in the wage share of income); and open economy effects, which render either trade flows sensitive to changes in relative prices, or capital flows sensitive to profit rate differentials across national borders. Blecker's conclusion is that while capitalist economies can be either stagnationist or exhilarationist and exhibit either wage-led or profit-led growth in principle, recent changes in fiscal policy, workers' saving behaviour and the globalization of trade and capital flows may have made exhilarationist and/or profit-led growth outcomes more likely in contemporary capitalism. One way of thinking about this result is in terms of the importance of the institutional structure of capitalism (including its policy norms) in determining the influence of distribution on growth.

A common misconception in macroeconomics is that Keynesian economics is centred on imperfections (such as wage and/or price rigidities, or expectational errors) that create demand-constrained outcomes in the short run, whereas in the long run, adjustments take place (in expectations or prices/wages) that automatically restore the economy to a position of supplydetermined equilibrium. Tracy Mott addresses this misconception by using a Kaleckian model of the short run to study the impact on macroeconomic outcomes over time of changes in longer-run factors, such as the quantity and type of capital used in production, and the conditions of competition between firms. The point is to explore the possible evolution of an economy from a position of short-run equilibrium when these longer-run factors are allowed to change - the point being that the conventional conception of automatic convergence towards a supply-determined equilibrium defined independently of demand conditions is simplistic and inaccurate. Instead, Mott uses the longer-run forces named above to help explain historical developments in twentieth-century US capitalism in the context of a modified Steindl model of secular stagnation. Instead of being the temporary result of various selfcorrecting aberrations, then, the Keynes-Kalecki short run is revealed as being the point of departure for study of the forces that determine accumulation and growth in a capitalist economy.

The chapters by Marc Lavoie and Mario Cassetti draw attention to the potential interplay of the conflict theory of inflation and Kaleckian growth theory. Lavoie develops a mechanism, based on the conflict theory of inflation, which reconciles the actual and target rates of return in a Kaleckian 
growth model. ${ }^{15}$ A standard Kaleckian growth model is first developed, exhibiting both the paradox of thrift (an increase in the propensity to save reduces the rates of profit and growth) and the paradox of costs (an increase in real wages increases the rates of profit and growth). One problem with this model is that the actual and target rates of return (and hence the actual and normal rates of capacity utilization) need not be equal in the long run. When a mechanism that causes the target rate of return to adjust towards the actual rate is introduced, this problem is solved - but at a cost. The paradox of costs disappears.

Lavoie then introduces the conflict theory of inflation, in which inflation is a function of inconsistencies in the income aspirations of workers and firms. He shows that when this model of inflation is combined with the standard Kaleckian growth model, the latter exhibits the paradox of thrift. Moreover, when a mechanism that causes the target rate of return to adjust towards the actual rate is introduced, not only are these rates of return equalized in the long run, but the rate of capacity utilization remains endogenous. This ensures that the model also exhibits the paradox of costs.

Mario Cassetti further develops this marriage of conflict inflation and Kaleckian growth theories by considering a two-way interaction between the rates of capacity utilization and growth on one hand, and the distribution of income on the other. This is done by first integrating a conflict inflation model into a Kaleckian growth model, as in the previous chapter. In the resulting model, changes in distribution can affect capacity utilization and growth, as in the standard Kaleckian model. But these changes in capacity utilization and growth are then allowed to have feedback effects on the dynamics of wageand price-setting behaviour and hence the distribution of income, operating via their influence on the bargaining power of workers and firms.

Cassetti shows that either a positive or negative relationship between capacity utilization and the profit share can emerge, depending on whether increases in the utilization rate enhance the bargaining power of firms relative to that of workers, or vice versa. As a result, a variety of equilibrium positions can emerge, which differ according to the profit shares of income and the rates of growth and capacity utilization associated with them, depending on (among other things) whether it is the relative bargaining power of firms or workers that is enhanced by increases in the rate of capacity utilization. An extension of the model to an open economy setting reveals that the equilibrium rate of capacity utilization in a closed economy may not be sustainable in an international environment, if the resulting rate of inflation exceeds that of the rest of the world. Ruling out the possibility of continuous exchange rate depreciation, the economy is confronted with two choices: deflate, or use an incomes policy to reconcile the competing income claims of workers and firms with the constraint imposed by external inflation. Once again, the analysis recalls the potential 
importance of the institutional environment in conditioning the outcomes of growth dynamics.

According to Kriesler (1999, p. 401) 'the traverse is at the same time one of the most important concepts in economic theory, and also one of the most neglected'. Mark Setterfield takes up this theme in the section on Traverse Analysis and Demand-led Growth, arguing that, despite being one of few Hicksian concepts to have languished in obscurity, the principle of the traverse is suggestive of a general method suitable for all macrodynamic analysis. He applies this idea to Kaldorian growth theory, reinterpreting Kaldor's cumulative growth schema as a traverse towards a steady state. The conditions and hence position of the latter are, however, shown to be sensitive to the traverse path itself. What emerges is a model of long-run growth that nests mediumterm episodes of cumulative causation within growth 'regimes', the structure of which is endogenous to the economy's past growth performance. The way in which this endogeneity - and hence the economy's path dependence - is modelled involves systemic openness and novelty, giving rise to what is described as evolutionary hysteresis. Ultimately, the model both extends Kaldorian growth analysis by allowing for endogenous changes in relative growth rates, and suggests an analytical framework that, because of its faithfulness to Kaldor's emphasis on historical process, may be conducive to the further development of Kaldorian growth theory.

Each of the chapters in the final section on Structural Change and Demandled Growth draws attention to the fact that growth involves not just the expansion of demand and productive capacity in the aggregate, but also changes in what is produced, how it is produced and for whom. These changes in the composition or structure of economic activity are, at once, influences on and influenced by the rate of growth in the aggregate, with which most growth analysis is, of course, solely preoccupied. George Argyrous notes that, although demand is a lead element in the growth process according to some economists, little attention has been devoted to theorizing the historical evolution of aggregate demand itself. Transformational growth theory, however, provides just such a historically based account of the evolution of demand, and the primary purpose of Argyrous's chapter is to outline this account.

Three key processes are identified as having been instrumental in the emergence and subsequent growth and development of mass markets in contemporary capitalism: the initial creation of a wage-labour (and hence non-self-sufficient) class; the productivity-enhancing (and therefore cost- and price-reducing) effects of industrial mass production; and changes in the composition of demand as personal incomes have grown. These developments in the market for consumer goods are then shown to stimulate the growth of demand for investment goods, as production itself is transformed in response to the transformational growth of consumer demand. This, in turn, further 
enhances the development of the mass market for consumer goods, the result being a cumulatively self-reinforcing process of growth in the demand for consumer and investment goods. Argyrous notes, however, that although industrial production and mass consumer markets have been subject to a virtuous circle of self-reinforcing growth in the past, their further growth and development is not inevitable. Instead, endogenously generated obstacles to growth - such as short-run limits to production in the capital goods sector, distributional effects or the increasing tertiarisation of the economy - may ultimately inhibit the growth process.

The chapter by Edward Nell returns to Argyrous's theme that theorizing the growth of demand is an important but underdeveloped pursuit in economics. Despite the fact that firms require an expansion of demand if they are to realize profits from the production of additional goods and services, most long-run macroeconomic theory simply assumes that demand responds passively to supply, so that the expansion of the latter is all that is of interest to growth theorists. Meanwhile, Nell argues that even theories that purport to take demand seriously in the long run - such as the Harrod-Domar and Cambridge growth models - are deficient in their treatment of demand.

Based on a critique of Lancaster's (1966) 'characteristics' theory of consumption, Nell develops a theory of the transformational growth of demand in which social pressures result in a demand for self-improvement which is, in turn, associated with both the growth of productivity and consumer demand. Particular attention is paid to the relationship between selfimprovement and the emergence of new markets (especially for services such as education and communications), which is identified as the sine qua non of sustained growth. A model of this process is used to shed light on the incentive to introduce new technology that is labour saving but capital using - a tendency that has been an enduring feature of capitalist economies. Furthermore, education and communications are identified as collective goods - goods that are not consumed individually (like ice-creams or sweaters) but by networks of users, thus creating interdependencies between consumers. Nell argues that the need to coordinate consumers of collective goods and to capture the network externalities associated with them enhances the role of the state, so that as an economy develops and the importance of collective goods increases, there is a tendency for government spending to increase as a proportion of total income. This expansion of the government sector further contributes to the expansion of markets set in motion by the quest for self-improvement, thus itself contributing to the processes by which growth in developed economies is sustained.

The interplay between patterns of consumer demand, productivity and the importance of networked activities brought to light in Nell's chapter provides the central focus of the final chapter in this volume, by Pascal Petit and Luc 
Soete. Petit and Soete begin by identifying three stylized facts associated with the current growth episode in capitalist economies - an increase in income inequality, skill-biased technological change in the workplace and polarization in the consumption of quality improvements in consumer goods - positing that these stylized facts are causally linked in a self-reinforcing process of cumulative causation. It is recognized that transitions between growth episodes are lengthy, so that the trends described above may be transitory effects of the slow diffusion of new information and communication technologies (ICTs) embodied in producer and consumer goods. But Petit and Soete argue that the potential exists for these trends to interact cumulatively and thereby influence long-run growth outcomes. In this scenario, a group of sophisticated consumers use their high incomes, human capital and access to intermediation services to create markets for 'high-tech', high-value-added output, in the production of which their skills and abilities to use intermediation services are also essential. Their consumption and production activities are thus mutually self-reinforcing - as are those of a group of less sophisticated, lower-income consumer/workers, who are simultaneously engaged in less technologically intensive and less remunerative production and consumption activities. This threatens to create a segmented or dualistic society that is less socially cohesive than the more economically unified Fordist growth regime, associated with the postwar (1945-73) Golden Age of capitalist growth. Moreover, the segmentation or dualism in patterns of consumption and production, by limiting the diffusion of and positive externalities associated with ICTs on both the demand and supply sides, threatens to inhibit the growth-enhancing potential of current technological change. Petit and Soete end with a review of the debates on skill-biased technological change and the mismeasurement of the consumer price index, designed to highlight some of the most significant connections between technology, learning and patterns of production and consumption.

\section{NOTES}

1. See also Chapters 2 and 3.

2. These issues are taken up in Chapter 7.

3. See McCombie and Thirlwall (1994) and Chapters 5-7 and 12 for further discussion of these various strands of Kaldorian growth theory.

4. Chapters 8-11 are illustrative of these developments.

5. See also Pasinetti (1981) and Petit (1986) for discussions of the importance for growth of economic structure, and Cornwall and Cornwall (1994) for a more recent exposition of the ideas described above.

6. Chapters 13-15 discuss the relationship between demand-led growth and economic structure, including the structure of demand itself.

7. In fairness, it should be noted that some neoclassical analyses do entertain the possibility that short-run variations in aggregate demand can affect the economy's potential output path 
and hence long-run rate of growth (see, for example, Blackburn 1999). But this hypothesis is strictly peripheral to the core of neoclassical growth theory, which claims that long-run growth is determined by factors on the supply side of the economy. There is certainly no truth to the suggestion that aggregate demand is viewed as a necessary constituent of growth analysis in neoclassical theory. This is, however, precisely the view held by advocates of demand-led growth theory.

8. It may be objected that, by defining the economy's potential output at any point in time, the conditions of supply define a 'ceiling' below which the actual output path described above must lie. But this ceiling concept merely serves to draw attention to the general importance of effective demand failures in demand-led growth theory, as a result of which the economy is normally expected to suffer a shortage of demand relative to potential supply. Moreover, the potential output path of the economy is not independent of its actual output path, as will become clear below.

9. See, for example, the chapters by Setterfield and Cornwall, Blecker, Mott, Lavoie and Cassetti.

10. See the chapter by Blecker in this volume for a survey of different investment functions embodying this principle.

11. Chapters 2, 5, 7 and 12 all make use of Kaldor's notion of endogenous technical progress. See also McCombie and Thirlwall (1994, p. 464) for a demonstration of the relationship between Kaldor's technical progress function and the Verdoorn law.

12. See Boyer and Petit (1991) and Setterfield (1997b, pp. 48-50) for further discussion of the sources of demand-led technical change.

13. McCombie and Robert's chapter is based on their 'Demand and economic growth from a Kaldorian perspective', Review of Political Economy, 15, forthcoming (http://www.tandf.co.uk).

14. Palley's chapter is reprinted from the Review of Political Economy, 15, forthcoming (http://www.tandf.co.uk).

15. Lavoie's chapter is based on his 'Kaleckian effective demand and Sraffian normal prices: towards a reconciliation', Review of Political Economy, 15, forthcoming (http://www.tandf.co.uk).

\section{REFERENCES}

Asimakopulous, A. (1975) 'A Kaleckian theory of income distribution', Canadian Journal of Economics, 8, 313-33.

Blackburn, K. (1999) 'Can stabilisation policy reduce long-run growth?' Economic Journal, 109, 67-77.

Boyer, R. and P. Petit (1991) 'Kaldor's growth theories: past, present and prospects for the future', in E.J. Nell and W. Semmeler (eds) Nicholas Kaldor and Mainstream Economics, New York, St. Martin's Press, 485-517.

Brouwer, E. and A. Kleinknecht (1999) 'Keynes-plus? Effective demand and changes in firm-level R\&D: an empirical note', Cambridge Journal of Economics, 23, 385-99.

Chick, V. and M. Caserta (1997) 'Provisional equilibrium in macroeconomic theory', in P. Arestis, G. Palma and M. Sawyer (eds) Markets, Unemployment and Economic Policy: Essays in Honour of Geoff Harcourt, Vol. II, London, Routledge pp. 223-47.

Cornwall, J. (1972) Growth and Stability in a Mature Economy, London, Martin Robertson.

Cornwall. J. (1977) Modern Capitalism: Its Growth and Transformation, London, Martin Robertson. 
Cornwall, J. and W. Cornwall (1994) 'Growth theory and economic structure', Economica, 61, 237-51.

Dixon, R. and A.P. Thirlwall (1975) 'A model of regional growth rate differences along Kaldorian lines', Oxford Economic Papers, 27, 201-14.

Harris, D. (1974) 'The price policy of firms, the level of employment and distribution of income in the short run', Australian Economic Papers, 13, 144-51.

Kaldor, N. (1957) ‘A model of economic growth', Economic Journal, 67, 591-624.

Kaldor, N. (1970) 'The case for regional policies', Scottish Journal of Political Economy, 18, 337-48.

Kaldor, N. (1972) 'The irrelevance of equilibrium economics', The Economic Journal, $82,1237-55$.

Kaldor, N. (1981) 'The role of increasing returns, technical progress and cumulative causation in the theory of international trade and growth', Économie Appliquée, 34, 593-617.

Kaldor, N. (1985) Economics Without Equilibrium, Cardiff, University College Cardiff Press.

Kalecki, M. (1971) 'Trend and the business cycle', in Selected Essays on the Dynamics of a Capitalist Economy, 1933-1970, Cambridge, Cambridge University Press.

Kriesler, P. (1999) 'Harcourt, Hicks and Lowe: incompatible bedfellows?' in C. Sardoni and P. Kriesler (eds) Themes in Political Economy: Essays in Honour of Geoff Harcourt, London, Routledge, pp. 400-417.

Lancaster, K. (1966) 'A new approach to consumer theory', Journal of Political Economy, 74, 132-57.

Lucas, R.E. (1988) 'On the mechanics of economic development', Journal of Monetary Economics, 22, 3-42.

McCombie, J.S.L. and A.P. Thirlwall (1994) Economic Growth and the Balance of Payments Constraint, London, Macmillan.

Nell, E.J. (1992) Transformational Growth and Effective Demand, London, Macmillan.

Pasinetti, L. (1981) Structural Change and Economic Growth: A Theoretical Essay on the Dynamics of the Wealth of Nations, Cambridge, Cambridge University Press.

Petit, P. (1986) Slow Growth and the Service Economy, New York, St. Martin's Press.

Robinson, J. (1956) The Accumulation of Capital, London, Macmillan.

Romer, P. (1986) 'Increasing returns and long-run growth', Journal of Political Economy, 94, 1002-37.

Rowthorn, R.E. (1982) 'Demand, real wages and economic growth', Studi Economici, $18,3-53$.

Schmookler, J. (1966) Innovation and Economic Growth, Cambridge, MA, Harvard University Press.

Setterfield, M. (1997a) 'Should economists dispense with the notion of equilibrium?' Journal of Post Keynesian Economics, 20, 47-76.

Setterfield, M. (1997b) Rapid Growth and Relative Decline: Modelling Macroeconomic Dynamics with Hysteresis, London, Macmillan.

Solow, R. (1956) 'A contribution to the theory of economic growth', Quarterly Journal of Economics, 70, 65-94.

Thirlwall, A.P. (1979) 'The balance of payments constraint as an explanation of international growth rate differences', Banca Nazionale Del Lavoro Quarterly Review, $128,45-53$. 